\title{
Treatment of compensatory hyperhidrosis of the trunk with radiofrequency ablation
}

\section{Radyofrekans ablasyon ile gövde kompansatuvar hiperhidrozun tedavisi}

\author{
Süleyman DENIZ, ${ }^{1}$ Kuthan KAVAKLI, ${ }^{2}$ Hasan ÇAYLAK, ${ }^{2}$ Tarık PURTULOĞLU, ${ }^{3}$ Ersin SAPMAZ, ${ }^{2}$ \\ Gökhan INANGIL, ${ }^{1}$ Abdulkadir ATIM, ${ }^{3}$ Sedat GÜRKÖK, ${ }^{2}$ Ercan KURT ${ }^{3}$
}

\section{Summary}

Objectives: Although Endoscopic Thoracic Sympathectomy is a widely accepted treatment method for patients with palmar hyperhidrosis, compensatory hyperhidrosis of the trunk remains a challenging side effect of the procedure. No satisfactory treatment options for this side effect were available until now. In this study, we aimed to define a new procedure for the treatment of compensatory hyperhidrosis of the trunk.

Methods: A total of 10 patients admitted our institution for the treatment of compensatory hyperhidrosis of the trunk were enrolled in the study between November 2010 and January 2012 in a prospective manner. Sympathetic blockage was achieved via radiofrequency thermo-ablation technique. The results of treatment were evaluated via telephone calls.

Results: Ten patients ( 2 females, 8 males) underwent radiofrequency thermo-ablation of T6 sympathetic ganglion for compensatory hyperhidrosis of the trunk. The mean age was 29.2 years and the median duration of symptom was 10.5 months. The median follow-up period was 14 months. Six of ten patients (60\%) were treated successfully. There was no procedure related complication.

Conclusion: The radiofrequency treatment for patients with compensatory hyperhidrosis of the trunk is an alternative option with promising results.

Key words: Compensatory hyperhidrosis; radiofrequency; sympathectomy.

\section{Özet}

Amaç: Endoskopik torasik sempatektomi palmar hiperbidrozu olan hastalar için yaygın kabul gören bir tedavi yöntemi olmasına rağmen, gövde kompansatuvar hiperbidrozu bu prosedürün çözümsüz bir yan etkisi olarak görülebilmektedir. Bu problem için tatmin edici bir tedavi yöntemi bugüne kadar tanımlanmamıştır. Bu çalı̧mada, gövde kompansatuvar hiperbidrozu tedavisinde yeni minimal invaziv bir tedavi yöntemi tanımlamasının yapılması amaçlanmıştır.

Gereç ve Yöntem: Palmar hiperbidroz nedeniyle endoskopik torasik sempatektomi uygulanan ve gövde kompansatuvar hiperbidrozu gelişen 10 bastaya (2 kadın, 8 erkek) ileriye yönelik olarak Kasım 2010 ve Ocak 2012 taribleri arasinda sempatik radyofrekans termokoagülasyon tekniği ile T6 seviyesinden ablasyon uygulandı. Tedavinin sonuçları telefon görüşmeleri ile değerlendirildi.

Bulgular: Yaş ortalaması 29.2 yıl idi ve semptom ortalama süresi 10.5 ay idi. Ortalama takip süresi 14 ay idi. Altı basta (\%60) başarılı bir şekilde tedavi edildi. Tanımlanan yönteme bağl yeni bir komplikasyon görülmedi.

Sonuç: Gövde kompansatuvar hiperbidroz hastalarında T6 seviyesinden uygulanan radyofrekans ablasyon tedavisi ile ümit verici bu sonuca ulaşılmıştır. Bu amaçla daha fazla çalışma yapılması gerektiği düşüncesindeyiz.

Anahtar sözcükler: Kompansatuvar hiperhidroz; radyofrekans; sempatektomi.

Bu yazının özeti 39th ASRA Meeting kongresinde poster bildiri olarak sunulmuştur (3-6 April, 2014, Chicago, Illinois, USA).

'Department of Anesthesiology, Haydarpasa Training Hospital, Gulhane Military Medical Academy, Istanbul, Turkey;

${ }^{2}$ Department of Thoracic Surgery, Gulhane Military Medical Academy, Ankara, Turkey;

${ }^{3}$ Department of Anesthesiology and Reanimation, Gulhane Military Medical Academy, Ankara, Turkey

'Gülhane Askeri Tıp Akademisi, Haydarpaşa Eğitim Hastanesi, Anesteziyoloji ve Reanimasyon Servisi, İstanbul;

${ }^{2}$ Gülhane Askeri Tıp Akademisi, Gögüs Cerrahisi Anabilim Dalı, Ankara;

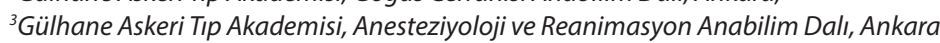

Submitted (Başvuru tarihi) 30.12.2013 Accepted after revision (Düzeltme sonrası kabul tarihi) 01.07.2014

Correspondence (iletişim): Dr. Süleyman Deniz. Gata Haydarpaşa Anesteziyoloji ve Reanimasyon Servisi, 34100 istanbul, Turkey.

Tel: +90-216- 5422020 e-mail (e-posta): sdeniz.md@gmail.com 


\section{Introduction}

Compensatory hyperhidrosis $(\mathrm{CH})$ of the trunk is a challenging side effect of palmar hyperhidrosis treatment. Although satisfaction of patients, who were treated surgically for their local excessive sweating, is almost exclusively related to this side effect, its prevelance following endoscopic thoracic sympathectomy is quite high ranging between $14 \%$ and $90 \%$ in different series. In about $30 \%$ of all cases $\mathrm{CH}$ was reported to be severe. ${ }^{[1]}$

Currently, the main objective of hyperhidrosis treatment has shifted from improving the efficiency of treatment to the avoidance of $\mathrm{CH}$. The level and the number of sympathectomized ganglions are the most well known factors to prevent $\mathrm{CH} \cdot{ }^{[2-5]}$ Clipping of the sympathetic chain is an alternative option for sympathetic blockage which can be removed when $\mathrm{CH}$ occured. ${ }^{[6,7]}$ However, an experimental study has showed that the procedure is not fully reversable even after removal of clips so $\mathrm{CH}$ persists in most of the cases. ${ }^{[8]}$

Injection of botulinum toxin-A to the focal skin area was found to be a well-tolerated, effective, and safe method for $\mathrm{CH}$. However, this treatment option does not provide a permanent relief. ${ }^{\left[{ }^{[}\right.}$

Proper management of $\mathrm{CH}$ following sympathectomy is of paramount importance. In this study, we aimed to present a new treatment option for $\mathrm{CH}$.

\section{Materials and Methods}

\section{Patients}

A total of 219 sympathectomy procedures at various levels for patients with 97 palmar (T4), 68 axillary (T3 or T2-3) and 54 palmar-axillary (T3-4) hyperhidrosis were performed between January 2006 and December 2011. Among these, 10 patients (7 pa- tients T2-3, 2 patients T3 and 1 patient T3-4) who developed severe $\mathrm{CH}$ of the trunk were enrolled in the study between November 2010 and January 2012. CH were evaluated according to the classification of Purtuloglu et al. (Table 1). All patients gave written informed consent and the study was approved by local ethic committee.

\section{Surgical procedure}

For the sympathectomy or sympathicotomy, all of the patients underwent general anesthesia via double lumen endotracheal intubation. The patients were in semi-fowler position. Following single lung ventilation, a one $\mathrm{cm}$ insicion was performed in the midaxillary line at fifth intercostal space and a five $\mathrm{mm} 0^{\circ}$ thoracoscope and endoscopic hook cautery were introduced from the insicion. The sympathetic chain was cauterized for sympathicotomy. A $28 \mathrm{~F}$ chest tube was placed to evacuate air between plevral surfaces. When pneumothorax evacuation was completed, chest tube was removed. Control chest Xrays were obtained at early postoperative period. The procedures were performed by different surgeons qualified at this procedure.

\section{RF technique}

For the treatment of compensatory hyperhidrosis of the trunk, normal prothrombin time and platelet counts were provided from all patients. Following an insertion of peripheral i.v. catheter, the patients were monitorized with ECG, oxygen saturation (SPO2) and non-invasive blood pressure. The sedation was achieved with $0.02 \mathrm{mg} / \mathrm{kg}$ i.v. midazolam. Patients were in prone position. The RF application was performed to all patients as detailed below: following subcutaneous local anesthesic infiltration, Cosman RFG-1A Lesion Generator (Cosman Medical, Inc., Burlington, Massachusetts, USA) was used for RF thermo-ablation (Figure 1). Under fluoroscopic guidance, $10-\mathrm{cm}$ lenght and $5-\mathrm{mm}$ diameter active

Table 1. Classification of compensatory hyperhidrosis ${ }^{[12]}$

\begin{tabular}{ll}
\hline Classification & Feature \\
\hline No compensatory hyperhidrosis & - \\
Mild & Sometimes noticeably sweaty and sometimes not sweaty \\
Moderate & Always aware but not troublesome, or troublesome but controlled by clothing \\
Severe & Causes embarrassment or regret over having had endoscopic thoracic sympathectomy \\
\hline
\end{tabular}




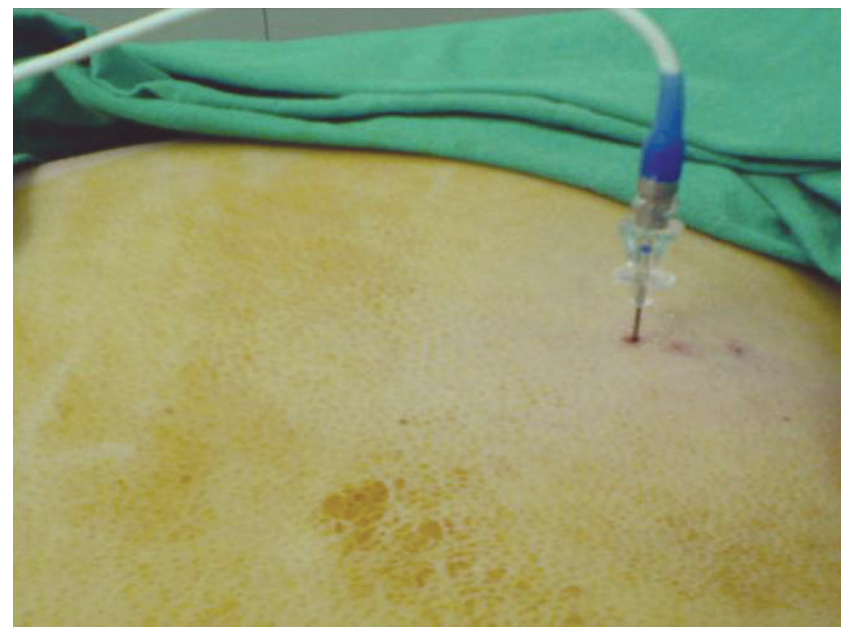

Figure 1. External view of RF application.

cannula of RF device was advanced to $\mathrm{T}_{6}$ sympathetic ganglion (Figure 2). When the probe reached to an appropriate point, the level of the cannula was ascertained with diffusion of injected radiopaque material over the parietal pleura. Then, the electrode of RF device was placed in the cannula and the impedance was kept between 220-400 ohm. In order to check the position of the cannula neurophysiologically, paresthesia observed with $50 \mathrm{~Hz}$ sensory stimulation and 0.3-0.5 V. No motor contraction observed with $2 \mathrm{~Hz}$ motor stimulation and 1.3-1.5 $\mathrm{V}$. After this neurophysiologic test, RF thermocoagulation was applied at $75^{\circ} \mathrm{C}$ for 90 seconds. Before thermocoagulation, $2 \mathrm{ml}$ of $2 \%$ lidocaine was applied into the cannula. All patients were followed for development of potential complications such as pneumothorax, bradicardia and major hematoma for two hours.

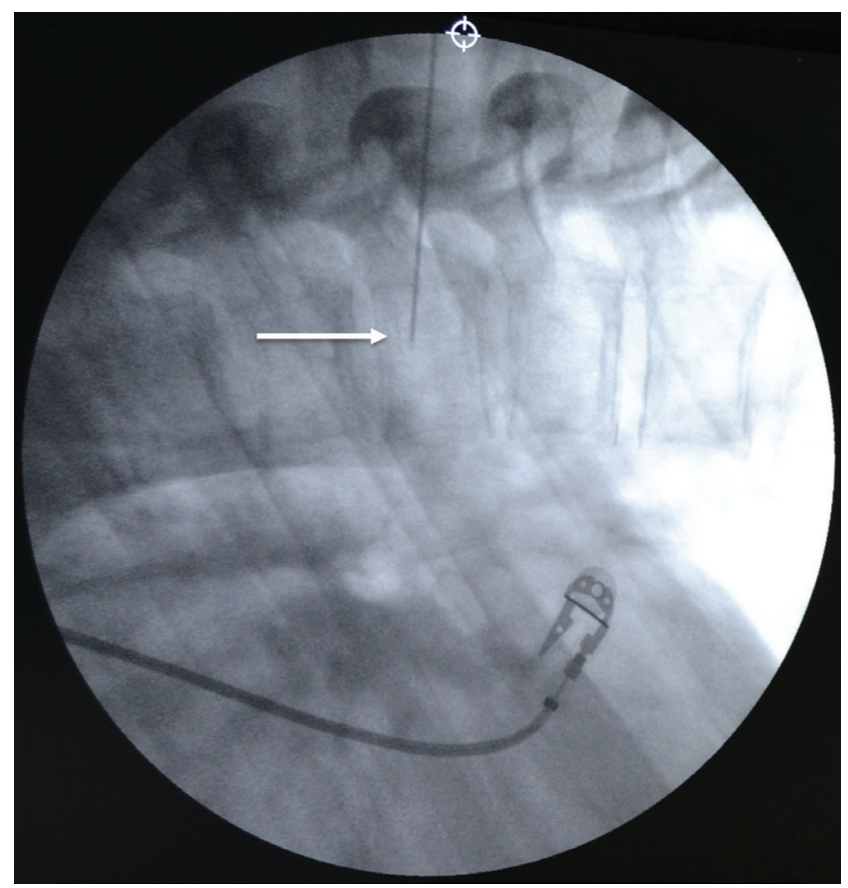

Figure 2. Lateral view of the cannula under flouroscope. The white arrow indicates the corpus of $\mathrm{T}_{6}$ vertebra.

We have contacted with all patients via telephone. Patients were questioned about improvement of their symptoms (dry, fairly dry, not dry) and were asked to grade their satisfaction rate on a scale from very satisfied, satisfied to not satisfied. All the interviews were recorded.

\section{Results}

Eight male and two female patients enrolled in the study. The mean age was 29.2 years (range, 20-49 years) and the median duration of symptom was

Table 2. Patient characteristics and treatment results

\begin{tabular}{lcccccc}
\hline $\begin{array}{l}\text { No. of } \\
\text { patient }\end{array}$ & Sex & Age & $\begin{array}{c}\text { Period of } \\
\text { follow-up } \\
\text { (months) }\end{array}$ & $\begin{array}{c}\text { Duration of } \\
\text { symptom } \\
\text { (months) }\end{array}$ & $\begin{array}{c}\text { Patient } \\
\text { satisfaction scale } \\
\text { (>6 months) }\end{array}$ & $\begin{array}{c}\text { Post-treatment } \\
\text { status } \\
(>\mathbf{6} \text { months })\end{array}$ \\
\hline 1 & Male & 29 & 12 & 12 & Very satisfied & Dry \\
2 & Male & 49 & 15 & 6 & Satisfied & Fairy dry \\
3 & Male & 25 & 26 & 12 & Not satisfied & Not dry \\
4 & Female & 23 & 13 & 12 & Not satisfied & Not dry \\
5 & Male & 25 & 16 & 6 & Satisfied & Dry \\
6 & Male & 27 & 16 & 6 & Very satisfied & Dry \\
7 & Female & 33 & 9 & 48 & Not satisfied & Not dry \\
8 & Male & 23 & 7 & 12 & Satisfied & Fairy dry \\
9 & Male & 38 & 17 & 9 & Not satisfied & Not dry \\
10 & Male & 20 & 6 & 6 & Satisfied & Fairy dry \\
\hline
\end{tabular}


10.5 months (range, 6-48 months). The follow-up was complete for all patients and the median followup period was 14 months (range, 6-26 months).

Following RF application symptoms were improved in six patients $(60 \%)$ while in the remaining four patients RF thermo-ablation was not satisfactory. The characteristics of patients and treatment results were summurized at Table 2 . No procedure related early or long term complications were observed.

\section{Discussion}

Compensatory hyperhydrosis of the trunk is a frequent and troublesome side effect of hyperhydrosis treatment such that the possibility of $\mathrm{CH}$ has held physicians back from more effective therapy options. The issue is so relevant that several studies had been conducted to prevent or cure this unwilling effect.

The exact mechanism of $\mathrm{CH}$ has not been fully understood yet. Chou et al. ${ }^{[6]}$ deemed the changes in sweating pattern as a reflex response of the sweating center of hypothalamus and recommended the term 'reflex sweating' instead of compensatory hyperhidrosis. In study they reported a higher prevelance of severe $\mathrm{CH}$ following $\mathrm{T}_{2}$ sympathectomy and proposed the afferent negative feedback sympathetic signal as the operating factor. ${ }^{[6]}$ The level of sympathectomy is one of the most important factors in development of $\mathrm{CH}$ with higher levels related to higher risk. In another study Wolosker et al. ${ }^{[10]}$ performed $\mathrm{T}_{4}$ sympathicotomy on 46 patients for palmar hyperhidrosis and none of the patients experienced severe $\mathrm{CH}$. Purtuloglu et al. studies also showed similar results. ${ }^{[11,12]}$

Clipping is a sympathetic blockage technique which has been performed widely for the treatment of hyperhidrosis. It is similar to other sympathetic activity denervation techniques such as coagulation, cutting and segment removing in regard of safety, efficiency and feasibility. ${ }^{[13]}$ This technique is of worth due to its reversible nature and possible role in treatment of $\mathrm{CH}$. The advantage of this technique includes removal of the clips in a case of $\mathrm{CH}$ development. However the procedure is not fully reversible hence the regenaration of sympathetic chain is limited so $\mathrm{CH}$ may persist even after clip removal. Loscertales et al. $^{[8]}$ observed no nerve regeneration following clip removal in their experimental study and argued againts offering clipping method to patients as a reversible option. In a clinical study Sugimura et al. ${ }^{[7]}$ reported improved $\mathrm{CH}$ symptoms in 15 of 31 patients (48\%) after removal of clips. The improvement of $\mathrm{CH}$ can not be fully predicted after reversal. So this clinical approach is far away from being a satisfactory treatment option.

Topical glycopyrrolate is a choice of treatment for different types of local hyperhidrosis. The mechanism of glycopyrrolate in the hyperhidrosis treatment is via prevention of acetylcholine-induced stimulation of sweat gland receptors. In a prospective clinical trial which was performed by Cladellas et al. ${ }^{[14]}$ topical glycopyrrolate administration to the compensatory hyperhidrosis area was found effective in controlling symptoms. Long-term efficiency and safety results of treatment is not known and anticholinergic side effects of glycopyrrolate such as dry mouth, visual disturbance, urinary retention, urgency, flushing, and constipation should be kept in mind. In our study, we have a 14 month median follow-up and the effect of the treatment was persistant over this period. We observed no procedure related complication.

Intradermal injection of botulinum toxin-A is another choice of treatment for local hyperhidrosis such as palmar or axillary. Compensatory hyperhidrosis can be accepted as a local side effect and can be treated with botulinum toxin-A. Althought the technique is well-tolerated, effective, and safe method, the cost and discomfort due to injections limit its widespread use. Subsiding of treatment effect is another disadvantage. ${ }^{[9]}$ So this option should be regarded as a temporary approach for symptom-relief, not a definitive treatment option.

Surgical treatment attempts had been reported also. In the single case report, the patient underwent injection of botulinum toxin-A via VATS and after two months following intervention, he underwent thoracotomy. ${ }^{[15]}$ The treatment approach is very aggresive for a non-life threatening disorder like $\mathrm{CH}$. Our treatment procedure is also invasive but it does not require general anestesia and is performed on an out-patient basis. 
Current treatment options in treatment of $\mathrm{CH}$ were limited secondary to their unpredictable efficiency with temporary course and untoward side effects. Present report proposes RF application as an alternative method which provides long term symptom relief with high safety profile.

\section{Conclusion}

Radiofrequency thermo-ablation can be an alternative technique in the treatment of $\mathrm{CH}$ of the trunk with high safety profile, success rate and out-patient performing. The procedure is feasible and has leading nature in surgical area.

\section{Conflict-of-interest issues regarding the author- ship or article: None declared.}

\section{Peer-rewiew: Externally peer-reviewed.}

\section{References}

1. Dumont P. Side effects and complications of surgery for hyperhidrosis. Thorac Surg Clin 2008;18(2):193-207. CrossRef

2. Kim WO, Kil HK, Yoon KB, Yoon DM, Lee JS. Influence of T3 or T4 sympathicotomy for palmar hyperhidrosis. Am J Surg 2010;199(2):166-9. CrossRef

3. Liu Y, Yang J, Liu J, Yang F, Jiang G, Li J, et al. Surgical treatment of primary palmar hyperhidrosis: a prospective randomized study comparing T3 and T4 sympathicotomy. Eur J Cardiothorac Surg 2009;35(3):398-402. CrossRef

4. Li X, Tu YR, Lin M, Lai FC, Chen JF, Dai ZJ. Endoscopic thoracic sympathectomy for palmar hyperhidrosis: a randomized control trial comparing T3 and T2-4 ablation. Ann Thorac Surg 2008;85(5):1747-51. CrossRef

5. Ishy A, de Campos JR, Wolosker N, Kauffman P, Tedde ML, Chi- avoni $\mathrm{CR}$, et al. Objective evaluation of patients with palmar hyperhidrosis submitted to two levels of sympathectomy:T3 and T4. Interact Cardiovasc Thorac Surg 2011;12(4):545-8.

6. Chou SH, Kao EL, Lin CC, Chang YT, Huang MF. The importance of classification in sympathetic surgery and a proposed mechanism for compensatory hyperhidrosis: experience with 464 cases. Surg Endosc 2006;20(11):1749-53. CrossRef

7. Sugimura H, Spratt EH, Compeau CG, Kattail D, Shargall Y. Thoracoscopic sympathetic clipping for hyperhidrosis: long-term results and reversibility. J Thorac Cardiovasc Surg 2009;137(6):1370-7. CrossRef

8. Loscertales J, Congregado M, Jimenez-Merchan R, Gallardo G, Trivino A, Moreno S, et al. Sympathetic chain clipping for hyperhidrosis is not a reversible procedure. Surg Endosc 2012;26(5):1258-63. CrossRef

9. Kim WO, Kil HK, Yoon KB, Noh KU. Botulinum toxin: a treatment for compensatory hyperhidrosis in the trunk. Dermatol Surg 2009;35(5):833-8. CrossRef

10. Wolosker N, Yazbek G, Ishy A, de Campos JR, Kauffman P, Puech-Leão P. Is sympathectomy at T4 level better than at T3 level for treating palmar hyperhidrosis? J Laparoendosc Adv Surg Tech A 2008;18(1):102-6. CrossRef

11. Purtuloğlu T, Deniz S, Atım A, Tekindur Ş, Gürkök S, Kurt E. A new target of percutaneus sympathic radiofrequency thermocoagulation for treatment of palmar hyperhidrosis: T4. Agri 2013;25(1):36-40. CrossRef

12. Purtuloglu T, Atim A, Deniz S, Kavakli K, Sapmaz E, Gurkok S, et al. Effect of radiofrequency ablation and comparison with surgical sympathectomy in palmar hyperhidrosis. Eur J Cardiothorac Surg 2013;43(6):e151-4. CrossRef

13. Cerfolio RJ, De Campos JR, Bryant AS, Connery CP, Miller DL, DeCamp MM, et al. The Society of Thoracic Surgeons expert consensus for the surgical treatment of hyperhidrosis. Ann Thorac Surg 2011;91(5):1642-8. CrossRef

14. Cladellas E, Callejas MA, Grimalt R. A medical alternative to the treatment of compensatory sweating. Dermatol Ther 2008;21(5):406-8. CrossRef

15. Efthymiou CA, Thorpe JA. Compensatory hyperhidrosis: a consequence of truncal sympathectomy treated by video assisted application of botulinum toxin and reoperation. Eur J Cardiothorac Surg 2008;33(6):1157-8. CrossRef 